\title{
Roots and Philosophy of Russian Entrepreneurship*
}

\author{
Natalia Kusnezova ${ }^{* *}$
}

"People are doing their history themselves but not in the way they think they do, under the circumstances they did not choose... Traditions of all the previous died generations burdens the brains of alive as a nightmare".

Karl Marx: Eighteen's Brumer of Luis Bonapart

This article is dedicated to the problem of the Russian entrepreneurship development through the historical context of traditions, attitudes and mentality change. It embraces the vast period of the so called "Russian-Soviet-Russian“ economic history stressing the entrepreneurship continuity.

In dieser Arbeit wird die Entwicklung des unternehmerischen Denkens und Handelns in Rußland mit Blick auf die Veränderungen in den Traditionen, Einstellungen und Mentalitäten behandelt. Sie erfaßt die als „russischsowjetisch-russisch" charakterisierte Periode der Wirtschaftsgeschichte und versucht die Kontinuität des russischen Unternehmertums darzustellen.

${ }^{*}$ manuscript received: 14.07.97, revised: 22.01.98, accepted: 05.06.98

This paper is written on the liaison of several disciplines: economics, history, sociology and philosophy. There are used not only articles and monographs of these sciences but materials and experience of the author herself as well as sociological interviews of St. Petersburg branch of the Russian Academy of Science (Institute of Sociology). In „new Russians“ strata analysis of A. Touraine (1981), the so called „Sociological intervention" method, is applied supposing deep and long-run discussion with the representatives of the group under consideration. There were entrepreneurs differentiated according to the start-up position (engineers, researchers, workers, retired military officers, medical employees, nomenclature of average level) and to their business activities (industry, trade, insurance, service industry).

${ }^{* *}$ Professor for Economics at the Sankt Petersburg State University, Russia 


\section{Introductory Remarks}

Today there is no need to convince anybody in the necessity of reforming Russia and other countries of Central and Eastern Europe. The problem is to select the appropriate ways and the right dynamics of transformational changes. The differences in reform's variants from American to Chinese do not mean the absence of common features between them. All economic programmes suppose the accomplishment of national traditions and psychology, economic views and practice. The general common rules of transition from the centrally-planned to the market model of economic development is modified by national features and peculiarities and influenced by one of the key figures of the market relations entrepreneur.

Business is associated not only with economic performance but also with cultural, ethical, historical and socio-economic factors which are so important to be understood and investigated in this context in the transformational Russia. These are the following reasons:

1.) There is an obvious negligence of the business ethics in Russia based (as well as western ethics) on the Christian culture and ethical norms. It makes the western businessmen to mistrust Russian new businessmen and it is hardening commercial ties. This presupposes the necessity of the investigating the history of business ethics in Russia and to rehabilitate the significance of Christian basics in the Entrepreneurship.

2.) New Russian businessmen as well as ordinary Russians comprehend the market as a panacea against the ineffectiveness of the centrally-planned economy, they expect it to be an automatically regulated instrument without state influence, moved by irrational profit inspiration. Russian public does not understand that market has to be regulated by the government and connected with market rationality, that market spirit is oriented towards the consumer. Max Weber described the process of market rationality revolution in his classical "Protestant ethics and the spirit of capitalism". The technology of the rational market is universe and simple but inner psychological motivation is unique for each culture, for national religious and ethical norms. Grigorij Javlinskij in April 1997 interview for German journalists asserted "The post-Soviet Russian mentality is a explosive mixture of wild grass-root capitalism and equally wild communism". Russian entrepreneurial history and culture, economic traditions, system of entrepreneurial values and motivations are not known even by the most part of Russians.

3.) Post-Soviet Russia modernisation without respecting Russian mentality and ethics implementation has been proved to be unsuccessful. $20^{\text {th }}$ century's experience has shown that there is no universal way of modernisation and transformational changes from one economic system to the other. Sustainable development of any economic system is defined by the organic liaison of two 
foundations: traditions and innovations. Only reasonable interaction of Russian tradition and market innovation probably provides evolutionary and less painful market economy transformation.

4.) Economic traditions might be regarded as a spiritual factor defined by the archetype, mentality and ethics of the people and individuals. The consideration of this factor helps to analyse Russian economic traditions and future market economy development.

\section{The Russian Personal Mentality}

\subsection{Eastern and Western Christianity}

Christian understanding of a human being as the individual with a free will and free choice led to the new type of individuals having a new motivation to labour. "Free labour is the spiritual-economic force that appeared to be a fundament of the European culture" (comp. Bulgakov (1992)).

1.) Christianity reformed the inner world of individual, archetype of his psychology granting him highest religious freedom and proclaiming a salvation of the spirit as a goal and sense of individual human life.

2.) Christianity changed the individual self comprehension of people. Moral criteria became the crucial point of human being estimation.

3.) Christian understanding of good and evil provides the basis for people's attitude to different phenomena of economic life: labour, property, wealth, poverty. Creative, hard, industrious labour, honest property, public welfare service are appreciated as good and contempt to labour and dishonest property are estimated as bad.

4.) One of the main Christian traditions of Entrepreneurship is charity: aid to the poor, construction of churches, hospitals, schools etc.

The basics of the Russian and Western culture as well as ethics and mentality (including entrepreneurial) is Christianity: Catholic and Protestant wing in the West and Greek Orthodox religion - in Russia. Russian culture, economy, science, literature rise was connected with the development of Christian traditions and depression, and catastrophic periods - with the fall of Christianity.

It is reasonable not only to describe the difference between these cultures, ethical norms, mentality, etc. but to provide a reader with a analytical approach to the matter (See Table 1).

Western Christianity inherited Rome's energy of will, practical interest prevailing under mental mood, legislative approach to the social life when the connection between God and person is built on the contract foundation as a relationship between judge and prosecuted, borrower and creditor. Social 
relations between people in the West are considered as contract relations between autonomous people having strictly structured legislative base. Respect to the law, development of law obedient consciousness and the property rights became basics of the Western civilisation. The red line through all the history of Western Europe is a line of the raising individualism of a person who considered to be sovereign, law-obedient subject of the market relations following his own interests.

\section{Table 1: Basics of Western and Eastern Christian mentality}

\begin{tabular}{|l|l|}
\hline \multicolumn{1}{|c|}{ Western mentality } & \multicolumn{1}{|c|}{ Eastern mentality } \\
\hline God as an Almighty Judge $^{1}$ & $\begin{array}{l}\text { the connection between God and a person based on } \\
\text { God's Love and Mercy. }\end{array}$ \\
\hline Christian ethics is stronger than nature & „double faith“ and prevailing of ,night culture“ \\
\hline $\begin{array}{l}\text { practical interest prevailing under } \\
\text { mental mood; }\end{array}$ & prevailing of spiritual basics over the material. \\
\hline $\begin{array}{l}\text { legislative approach to the social life; } \\
\text { respect to the law, development of law } \\
\text { obedient consciousness and the } \\
\text { property rights }\end{array}$ & Faith, God's Grace, not in the power of Law". \\
\hline $\begin{array}{l}\text { raising individualism of a person. } \\
\text { Orientation to individual values and } \\
\text { the cult of the personal success }\end{array}$ & $\begin{array}{l}\text { raising of collectivism and communal consciousness. } \\
\text { Unification idea is non-economic, spiritual, irrational } \\
\text { faith in the Absolute Ideal. Particular interests of } \\
\text { different strata's and social groups are integrated for } \\
\text { the sake of the common purpose achievement. }\end{array}$ \\
\hline
\end{tabular}

Eastern Christianity - Greek Orthodox religion has another system of values. Its main basics is not a Justice of God but God's Love and Mercy. The search of the essence of life, sacred primary basics of life is in the centre of this system. In the Orthodox religion and culture socio-economic life is considered through inner transformation and lightening of a person. Unification idea of the Orthodox church people consists in the non-economic, spiritual, irrational faith in the Absolute Ideal. Particular interests of different strata and social groups are integrated for the sake of the common purpose achievement. Hence in comparison with the Western Christianity the Greek Orthodox culture is characterised by metaphysical consciousness and by prevailing of spiritual basics over the material.

1 The connection between God and a person according to the Old Testament was built on the contract basis. The Old Testament reflected Law. The New Testament implemented "God's Grace blessing the true faith" 
Christianity in Russia was accepted on the ground of already existing pagan primitive culture as well as in other civilisations. Synthesis of Christian and primary ancient Russian consciousness defined three main components of the personal archetype in Russia.

1. "Double faith". The Russians in their inner structure are the Eastern people. Russia is a Christian East which comprehends Western ideas in its cultural surface. Russia is developing catastrophically through discontinuities and changes of civilisation. Russians had to conquer huge territories, there were a lot of dangers from the East and from the West. Contradiction in the Russian soul was defined by the complexity of the Russian historical destiny, by the fight and collision of the eastern and western elements. The soul of the Russians was formed by the Russian Greek Orthodox Church. This religious formation was preserved through all the history including Russian nihilists and communists. But there is a very strong element of nature that is the consequence of the boundless Russian land. This primary natural element entered the Russian Christianity. In the Russian individual archetype these two elements, nature and religion, are always struggling. On one hand that is the primary nature, endless Russian lands, from the other hand Visantium asceticism, aspiration to the life beyond the grave, to the next, God's world. "The landscape of the Russian soul is adequate to the landscape of the Russian land... the same absence of bounds, forms, aspiration to eternity, width" (comp. Berdayev (1990) p. 8). While Christianisation of Russian local pagan traditions were not thrown away, on the opposite they were organically included in the new Christian culture.

"Double faith" - coexistence and growing through Christian and primitive grounds - led to the creation of the complex of behavioural stereotypes of Russia, made it stable and deep, became a basis for the 1000 years old Russian culture. People's festivities and ceremonies, „Father Sun“ and "Mother Land" cults were liaisoned and diffused with the Orthodox religion rituals. Some of the rituals connected with death, weddings, birthdays were divided into two parts done in the church and in the ordinary conventional everyday life. The Russians system of values was split into two parts as well: Christian values belonged to the higher level - faith in the souls salvation, moral merits, etc., on the second level there were values of the primitive culture connected with the material world, nature, human passions and happiness. In this system of values the second level prevailed although sins were restricted and charged keeping in mind that it's impossible to be sinless. Those who told that they have no sins were and are considered in the Russian morality worse than a murderer because he could not confess and hence be forgiven by God. There were negative sides in the double faith because this split happening in the people's consciousness led to G. Florovskij's "night culture" prevalence. This culture has no Christian grounds and was converted into the field of dreams and imagination that led to laziness, absence of will, contemplation, unreality, unpracticality, weakness of 
will. Multimentality of Russians in the adequate social contradictory environment was dangerous for the country so far as it predetermined the development of inadequacy between two ideologies: officially proclaimed and cultivated in the inner world of the people. (The most recent example of two ideologies coexistence was demonstrated during Bredznev's period). The religious formation of the Russian soul produced some stable properties: dogmatism, asceticism, ability to carry suffering and victims for the sake of the Russians faith whether it was orthodox religion either communism. The religious energy of the Russian soul is capable to convert from the religious into the social goals. According to the religious-dogmatical soul Russians are always either heretics, or orthodox, apocalyptic, or nihilists, revolutionaries or communists. The main property of Russians is their attachment to a certain orthodox religion.

2. "Faith, God's grace, not the Law". Faith always reflects historically formed self-consciousness of the people. There exists the behavioural imperative of different nations and people. For the Russians this imperative was created in XI and verbalised by Kiev Metropolitan Illarion in his tractate "The Word about Law and God's Grace". A reason for this tractate influence was the inspirations of Russians to the state and religious unification. The central idea of the "Word" is contradiction between Old Testament which reflects Law and New Testament - the God's Grace blessing the true Faith. The Law is an enforced and dependent form, establishing legislative norms, system of prohibitions under the fear of punishment. To the opposite God's Grace - is freedom, true consciousness. A human-being who lives according to the true faith becomes Christian not under somebody's permission or order, but according to the Christian truth. The Law is established only in one country and God's Grace is spread through all the countries including Roos. The Law is narrow and it splits, separates the peoples but the God's Grace is universal uniting all the peoples, faith is higher than the Law, than the utility. It liquidates the slavery of the Law. The Law is a shadow, the God's Grace, God's blessing Faith is truth. The enforcement of the Law is changed by the freedom of the individual and God's Grace. The behavioural criteria is not a fear or practical pragmatism but behaviour according to the inner Faith of a free person. We see in the Russian history this behavioural imperative assumed different forms but the sense stayed constant: "Make decisions in accordance with your Faith but not according to the Law".

3. Faith into the Absolute Ideal as a basis of the social relations. The unity and homogeneity of certain peoples and societies usually is reflected in the dominant system of values that is an indicator of differentiation between "ours" and "notours, others". According to this system there is formed dominant type of behaviour, principles of self-estimate and other individuals estimates forming public opinion of the society. In Germany, in my opinion, that is a principle of blood, in the USA - principle of business. In Russia - that is faith in the absolute 
values, high level of religious consciousness (not necessarily connected with church rituals). Unification role of absolute (high, communal) values in multinational and stratified Russia is very high. In pre-revolutional period Russia's stability and unification of the society was provided by Orthodox church religion, in the Soviet time - by communist ideology. An individual in Russia is acquiring his/her social status being attached to a dominating system of ideals and values. In the first place a person was considered to be Orthodox Christian (Soviet citizen) and then Ukrainian, Russian, Belorussian etc. As a result of this liaison one of the main feature of Russians was moral maximalism and messianity - a faith in particular special mission of Russia and Russians in the world. That was determined by the $16^{\text {th }}$ century crash of Visantium when Russia and Russians believed in their uniqueness as the only one Greek Orthodox state left in the whole world. According to their views and public opinion Moscow Roos became the only centre of true Universe and the Third Rome and Russians - the only holy sacred people. That idea laid in the basis of unique Moscow Russia formation and belonging to this tsarstvo was determined by the true Orthodox faith. The similar processes could be observed in the Soviet Russia when the belonging to the Russian Communist tsarstvo was determined by the ideology of orthodox communist faith.

During the periods when this faith in the Absolute Ideal and values was weakening we see the crash of the social relations and the state itself. The decrease of faith in 1917 led to the October Revolution, the collapse of the communist ideals accompanied by deep economic crisis - to the events of Perestroika and crash of the Soviet Union.

Proximity of an individual to the God, to Absolute permits him/her to solve his/her problems due to inner spiritual forces. Inner world personal orientation, its moral maximalism is expressed by patience - very essential Russian consciousness characteristic. Patience is considered by Russians as one of the highest human merits. „The God ordered us to be patient because he was patient", „Without patience there is no salvation" - these were (and are) widely spread sayings in Russia. But these principle could corrode in the process of the moral values degradation and crash. In this case another principle dominates the people's consciousness - "everything is permitted" and then Russian rebellion, bloodshed violence, almighty terror rule and reign Russians consciousness.

Russian maximalism leads to the very unfavourable tendency on the ordinary consciousness level - the propensity to search God's Kingdom ("Tsarstvo Bozije") on the earth, to the utopian mentality. This is reflected in the demands of the immediate radical transformation either through "proletarian revolution" or through "market reforms". 


\subsection{Russian Mentality and Ethics}

In the evolution of the society there exist two tendencies: individualism and collectivism („cathedrality“ in the Russian variant). Russia is not East with its collectivism assimilating human-being in the communal, collective, state structures. But Russia is not West either with the latter orientation to individual values and the cult of the personal success. It is possible to define the following indicators of the Russian mentality and ethics.

1.) Cathedrality, collectivism as a voluntary union of people accompanied by free, self-emancipation and self-revelation of a person. Cathedrality is presented in two forms: as psychological feeling and a type of activity. In the first case that means inspiration of people to highest (but not common) values, ideals uniting people and providing self-emancipation of a person in a "symphony of the common pray". In the second case cathedrality presents the union of people on the ground of active service to the social "earthy" ideals - defence of the country, triumph of justice, colonisation of new lands etc. Profession in this context is considered to be a public service to the others, voluntarily adopted duty. That's why in the ancient Russian literature historical characters were described not as individuals as such with their individual destinies but as one's acquiring a certain public role of a person (saint, duke, warrior, merchant).

2.) Communality - is a social form of voluntary union of people, that restricted the personal desires and aspirations, made a person to obey to the common interests and goals. Agrarian commune as an institutional incarnation/realisation/embodiment of communality was developed due to the necessity in labour co-operation, common economic questions solution, commune social stability and living standard provision.

Russian commune (mir, volost) had two main elements: communal management and collective use of land accompanied by the equal (due to the family members) land distribution and redistribution. The latter element was born in the $16^{\text {th }}$ century as a result of government fiscal policy. In 15-16 c. Russia implemented serfdom as a enforced attachment of the peasants to land without right to move to the other lands.

Until $16^{\text {th }}$ century land in the peasant's commune belonged to the peasants as a labour property and there was no enforced equalisation in land use.

The main function of the commune - peasant's self-management organisation for joint decision making in economy and social life. Current operational management was carried out by an elected person. State and gentry did not take part in this process. The church on the opposite participated very actively in economic, social and moral life of the peasant's commune.

These principles of the communal management was laid in the foundation of the social life of the Russian state. Until $18^{\text {th }}$ century the important institutes in state regulation were Land Councils that being a consultative organ played an 
essential role in the state policy. The representatives of all social groups from all over Russia gathered at this Councils and discussed state policy with the tsar and bojars making the most important political decisions. Legislative power in the institute of Councils was substituted by the power of the public opinion which compensated strong autocratic state power and restricted its tyranny. When the public opinion contrasted to the state no governmental measures could keep it from the crash and destruction (we watched it recently). When the power of the public opinion weakened there appeared a possibility of autocratic to despotic state conversion - and state terror flourishes. Hence a specific non-official public control over state is characteristic for Russia which never knew democratic institutions of the Western type.

The other specific feature of Russian ethics and mentality is contradiction of state and society. The latter cancels the burden of political power passing it to the authoritative government. The Russians have been always concentrating on their society duties: personal, family, communal, village, lands life etc. acquiring inner spiritual freedom.

3. Contradiction between state and individual. Through centuries there existed two contradictory forces: strong state and free active person. Historically it is connected with the enormous territories of Moscow Roos. The tsar as the only land owner often allotted land to a certain gentry but the latter refused from this gift: there were no people (warriors or peasants) as defenders and producers and hence no possibility to feed oneself and to buy military and civil equipment. The history of Russian principalities is a history of struggle for people. Before and during serfdom peasants emancipated themselves personally and ran from gentry, from the tsar to the North, East, South virgin huge lands where governmental suppression could no reach them. Strong patrimonial monarchy, absolute power of the tzar were accompanied by freedom of the people, their state, social and economic role, and were reflected in contradictory relationship between state and person in Russia. The following phenomena are specific for this relationship.

a) patriotic service to the state - evasion from the service. During the war time state and the people is united; if there is no danger - the people flew to the patches of land, to their inside world running away from state service.

b) worship of power - disrespect for power. Reverence (sometimes servile esteem) for the tsar or any monarch power was accompanied by disdain and contempt to authorities and inspiration to cancel, escape official authorisation that raise one's individual (particularly peasant's) social position. There was and is an opinion that only empty, non-serious, non-dignified people were (and are) inspired to get state position climbing up through the steps of a state career. A tradition to buy off from the official appointment and pass a post to a foreigner was very common for Russians. 
c) non-limited power of the monarch - his responsibility before his peoples, his subjects. The law did not have a norm that demands that the tsar is responsible before the people. The tradition was more demanding: for his deeds the tsar is responsible before God, conscience and the people. For failures and mistakes the monarchs pay with their heads. In the Russian fairy-tales that double attitude to the tsar was reflected in the disrespect to old, silly, greedy ruler in opposition to a young not very intelligent, but honest new-comer who successively jumping into a boiled milk and into an icy water (as a symbol of enlightenment) converted into a wise monarch.

d) strict centralisation of power - freedom in the local communities. $16^{\text {th }}$ century gave birth to the state terror from one side and Land Councils, the rise of freedom and self-management from the other. The Code of Laws Sudebnik 1550 put state officers under the direct control of these Councils.

Summing up we could define the following indicators of the Russian mentality and ethics.

1. Cathedrality collectivism as a voluntary union of people accompanied by free, emancipation of a person.

2. Communality.

3. State and individual. This relationship was reflected in the following phenomena

a) patriotic service to the state - evasion from the service.

b) high respect of power - disrespect and ignorance of power.

c) non-limited power of the monarch - his responsibility before his peoples, his subjects.

d) strict centralisation of power - freedom in the local communities.

\section{National Traditions in the Economy of Russia}

The above analysed features of archetype, mentality and ethics defined and still influences a role of the moral basics in economic traditions of Russian, system of values and peculiarities of entrepreneurial and labour ethics.

\subsection{The Attitude to Labour}

Industrious labour always was considered in Russia a moral deed, one of the main merits of a person.

Short summer, long and cold winter stimulated the Russian peasantry to work intensively, feverishly, within the bounds of possibility, on the utmost efforts during harvest-time and to do nothing during winter time. This explains an absence of custom to moderate, constant, measured, regular, steady labour. But 
natural factor and geography is not enough for the explanation o $f$ this least labour unevenness of Russians. The inspiration to the Absolute Ideal exists not only in the result but in the process of labour as well. If the inspiring purpose could be reached through a set of uninteresting boring actions a work itself seems to the Russian to be non-valuable and boring. Disgust to a work that was started, laziness in manufacturing details, carelessness, negligence, slipshod work are characteristic features for them. Russians who seems to be talented and capable people with original brains usually confine oneself only to an idea, do no more than a plan, a design of work without finalising it.

Russians according to their nature are win-loose characters. Everything or nothing - that is a credo of Russians. As far as Russians are inspired by Heavens, by some Absolute Ideal they could do something great: palaces and castles, a space craft, or fabulous Metro Station system in the big cities but they do not care about everyday life and well-being, daily needs, about medium level of culture, about tidy, neat houses, good roads, clean cities and villages.

\subsection{Attitudes to Property, Wealth, Prosperity, Charity, Philanthropy}

Private property in Russia did not receive such self-sufficing, legislative form as in the Western world where the principle of the private property lays in the ground of the personal mentality and ethics. Russians are convinced that "a human-being is higher than the principle of property" that is reflected in the social morality and economic relations ethics.

In the village world peasantry thought that the land is God's gift and belongs to those who cultivates it. Labour property rights were the basis for ownership. The Russian village communal world did not know individual private property. That does not result in collective property or in equalisation of distribution of the output. Traditional communal labour rights came from the principle of equal rights on land of all members of the commune proportional to quantity of labour hands provided that only a married peasant had a right to get land from a commune. Peasantry almost religiously referred to the labour products, but not to the gifts of nature considered as God's gifts. To steal a product from a field was a shame, but to cut a tree from a forest - a norm of using God's gift as natural as breathing.

The Russian encyclopedist of the $18^{\text {th }}$ century Tatischev characterising Russian mentality and business ethics wrote that "...the tranquillity of soul and conscience is a true wealth". Everyday prosperity is a living standard of the West. (Contemporary Russian inspiration to the Western standards demonstrates mostly a desire to finish with a poverty life style of the Soviet period, with a deficit of ordinary commodity goods rather than showing up one's prosperity or wealth). According to the foreigners justification and "Domostroj" of the $16^{\text {th }}$ century - a code of behaviour and set of rules in households - a living standard of the Russians was not low. 
Inspiration to autarchy, to autonomous existence, to provision of one's household with all the necessary products, economic independence were (and are) specific features of the economic behaviour in Russia. A village, a commune, a monastery tried to produce everything by themselves in the natural household. In this situation a Russian felt (and still feels) himself "light-hearted" but that was a feature of a thrifty, economical labourer who could hope only on one's hands and labour. A moderate, independent from others, prosperity, helping one's family but not challenging to others, arousing and provoking envy of the less fortunate members of the society were (and are) the features of ideal life-style.

Amalgamation of property and power is characteristic for Russia. Property has been considered as a duty (but not right) of the owner to fulfil a certain economic function in the system of state organism. In $18^{\text {th }}$ century, after the cancellation of the gentry's ("service estate") mandatory state service having land with attached peasants for this service, the antagonism between peasantry and gentry increased crucially. The latter could not accept an idea of working for those landlords who stopped carry their duty (military or administrative).

There is one more important point in relation to private property. Russian mentality accepts private property and predetermines division between poor and rich. But usually the ancient Russian literature following the consciousness of the people paid attention on ephemeral, momentary character of wealth, on the secondary of earthy benefits in comparison with heavenly, eternal spiritual goods. This phenomena explains the reason why Russians usually related and still relates tensely to those who devoted their life to the pursuit of earthy, temporary benefits. Wealth never had been a measure and a symbol of somebody's success in life; on the opposite, even if wealth's origin was legal its owner faces a certain public prejudice.

The wealthy people themselves felt the temporary and even "sinful" character of their wealth acquired from Entrepreneurship. Particular responsibility for wealth usage, exaggerated religiousness, propensity to confession were cultivated in the enriched people environment.

Relief from a burden of wealth, justification of wealth in one's own eyes and before the people was represented by philanthropy that was extremely widely spread not only in the biggest entrepreneurs (Tretijakov's, Morosov's, Tzvetaev's) but all over merchants estate of Russia. The state reduced the weight of taxes on entrepreneurs being sure that they will return this money by constructing schools, hospitals, churches, museums, supporting theatres, artists etc.

Russian entrepreneurs apprehend their success in business as a Christian cross a trial. They knew that they have received a lot and they have to repay a hundredfold. 


\subsection{Entrepreneurship as a Type of Occupation.}

The Institutional Pattern of Russian Entrepreneurship. The Artel.

Entrepreneurship in Russia started to develop long before Peter the Great epoch as a independent type of economic activity. Historically trade was the first form of Entrepreneurship. In Russia it had the following features.

1.) international character of trade as a professional activity was reflected in buying handicraft wares all over Russia and selling them in the whole-sale trade abroad;

2.) trade was usually connected with colonisation of new lands;

3.) trade and merchantry was often accompanied by the development of the home-industry;

4.) trade as an independent type of activities was converted to the governmental service due to the development of absolute patrimonial monarchy.

These are the stages of Russian Entrepreneurship:

1.) $18^{\text {th }}$ c.- protoindustrial;

2.) second half of the $19^{\text {th }} \mathrm{c}$. - bank and agrarian;

3.) beginning of the $19^{\text {th }} \mathrm{c}$. "the third estate" of Russia acquired a characteristics of independent bourgeoisie.

The Artel which transferred institutional and social principles of the peasant commune into industry and trade was the main institutional form of manufacturing and trade in Russia. In the „Code of Laws of the Russian Empire" the Artel was defined as a company found on the principles of joint expenses and joint responsibility for work and trade due to the labour of its members.

The members of the Artel were connected with the mutual pledge: everybody bears responsibility for the others and the Artel for everybody. Mutual responsibility - a specific feature of the Artel that was a ordinary type of cooperation of merchants, manufacturers, craftsmen, workers. Usually in the ground of their relationship there were relative or friendly companionship, personal acquaintance and mutual trust. Skilled qualified masters were the heads of the Artels.

Moral factors of labour stimulation prevailed over material. Qualitative and effective labour was stimulated not only by material reward but also by inner moral motivation so far as bad work is a sin blamed by the public opinion. Equalisation in income distribution was excluded from the Artel as unmoral. Before the WW I average wage level in the Artel reached $85 \%$ from the USA level and was higher than in Europe. This institutional form of management and 
organisation helped the Russians to escape collectivism of the East and individualism of the West.

\subsection{The Non-strict Profit Principle}

Entrepreneur's refusal from strict bargaining requirements followed by the obligatory profit maximisation is called non-strict profit principle. Profit gaining at any price was not characteristic for the Russians. "The profit has the highest priority but honour is higher than profit" was the motto of "Stock exchange News"- the financial newspaper of the $19^{\text {th }}$ century. This slogan of the ethical business was specific for Orthodox religious views according to which fraud, trickery, deception of buyers, partners, suppliers, employees was evil for which one should repay much more than gained profit. Most of the Russian entrepreneurs preferred to loose something rather than to suffer from the remorse and pricks of conscience. The examples of Orthodox faith merchant's deals and methods of trade described by Burischkin and Giljarovsky prove the trust to partners, loyalty to one's word even to one's detriment, usage of credits bearing no interest, loyal attitude to the competitor.

The Russian entrepreneurs had a specific non-official Code of Honour blaming all types of speculative and usury activities. Due to this Code Russian entrepreneurs were divided into two groups - honourable, respectful and nonhonourable, non-respectable. The first group consisted of manufacturers, merchants, financiers, traders that performed honourably without fraud. Usurers, money-lenders, speculators-middlemen, dealers trying to benefit due to the fraud and speculations were ascribed to the second group. This tradition accompanied the process of successful entrepreneurial (including credit and trade) activities development in the Ancient Roos. Usury and entrepreneurial credit were allowed in the Roos but high interest rate was considered to be immoral and nonchristian as well as income from usury - parasitic and non-labour-earned. When newcomers tried to avoid this non-written tradition they paid hundredfold. For example in 1113 in Kiev the peoples rebellion was catalysed by high speculation profits on commodity goods and interest of Jews-usurer. Their houses were destroyed and some of them murdered. Vladimir Monomach issued an Order limiting interest to the annual $20 \%$ but the main force contradicting high usury interest was a public opinion. In the West Catholic church tried to limit interest legally to $7-10 \%$ but without essential success.

Although the latter could earn a lot of money, respectable entrepreneurs attitude was extremely negative, because the existence of this non-respectable parasite group undermined the public trust towards Russian Entrepreneurship as a whole.

\subsection{The State paternalism}

Traditionally, beginning from Kiev Roos, Russian merchants took part in the political and social life, either co-operating or competing with the prince's 
power. In Novgorod Velikij a liaison of entrepreneurial spirit with selfmanagement led to unprecedented development of Entrepreneurship as well as to the emergence of the first trade city-republic.

In Moscow Roos the social and political role of the merchants was reduced under the influence of the centralised state formation particularly after Novgorod republic crushing defeat. Simultaneously under Ivan IV - the Threatening a regional lands self-management have been introduced: elected respectable persons gained a posts of judges, elected leaders managed regions and lands. Merchants being at the state service provided the strengthening of the state power and they took responsibility for important political and military decisionmaking during critical periods. This phenomena was demonstrated in the beginning of the $16^{\text {th }}$ century when the merchants gathered money and people's army for patriotic war and took part in the election of the new tsar Michail Romanov. Elected Land Council managed Russia during 10 years under Michail. Peter the Great's and Catherine the Great's Russia was characterised by decrease of political role of merchants with the simultaneous extreme development of state Entrepreneurship.

Strong positions of the state in the economy was displayed in donation of Entrepreneurship and "wardship" over it. The government was providing entrepreneurs with subsidies, donations because entrepreneur was on the "notice" of the government. The latter often did not get back debts from bankrupt entrepreneurs in the whole volume. The state could permit failures of certain entrepreneurs differentiating ordinary "throwing money" from failures in the useful undertaking beneficial for the country.

This practice often led to corruption, equalisation in state finances distribution, support of non-profitable, old-fashioned, backward enterprises as well as to the development of bureaucratic Entrepreneurship. From the other side state paternalism helped to stimulate investments in the most perspective, advanced industries.

In the beginning of the $20^{\text {th }}$ century market economy of Russia was on the starting point and entrepreneurs did not become a serious social power, serfdom and communal consciousness were very strong in the peasantry who mostly did not adopt stereotypes and ethics of the market behaviour. The country was searching for its own model of development.

The example of successful application of a new market economy model was P. A. Stolipin's agrarian reform as a final results of the $19^{\text {th }}$ century reforming attempts. The modernisation concept of the Russian economy proposed by Stolipin assumed the Russian way of the mixed economy formation, where state undertakings should compete with collective and local forms of enterprises. The main elements of this reform were transition to the land private property, agrarian middle-class formation, peasant's co-operation, beneficial (in fact free 
of charge) crediting of strong households, cheap peasant's credit institutions creation, state investments into agrarian infrastructure and education.

Stolipin and his cabinet with the help of direct state intervention, rotated credit and tax benefits, accelerated the market economy formation in agriculture and provided investments into industry. By the beginning of the WW I the rates of economic growth of Russia were the highest in the world. Revolution of 1917 interrupted Russian market economy development and Entrepreneurship formation but the beginning of the reforms of the 80-90-th started this process again.

\section{The New Russian Entrepreneurship}

First Russian investigations of Entrepreneurship appeared by the end of the $19^{\text {th }}$ - beginning of the $20^{\text {th }}$ century and a new wave of interest toward this phenomena is obvious now (comp. for instance Levschin (1812), Berch $(1831 / 33), \ldots$, Chromov $\left.(1988)^{2}\right)$.

The formation of Entrepreneurship started 1000 years ago together with the Russian state development.

In 1918 Entrepreneurship (as an activity connected with the profit gaining) was prohibited under death penalty (except the time period of NEP, the new economic policy of the young Soviet state 1921-1926, could be avoided as a zigzag of Bolshevik's policy temporarily accepted as a enforced measure necessary for salvation of the national economy) and escaped from the economic system of the centrally-planned economy itself. During several years entrepreneurs of Russia were liquidated (See Table 2):

By 1920 100thousands of entrepreneurs were liquidated either forced to immigrate. Until 1987 Entrepreneurship was considered to be crime.

The lost of this strata of the society meant unique social group liquidation which according to the mentality, ethics, life style, psychology, national specifics was different from the Western analogues. After 1987 ratification of the Individual Activities Law the Russian Entrepreneurship started to regenerate.

\subsection{Entrepreneurs in the transitional period context}

The death of communism and socialism in its Soviet variant does not mean an end of the history as well as does not mean farewell to the heroes of former years. What could be worth than socialism? Only something that goes after it. Post-communist society does not appear on the empty place. We do not act within uninhabited planet "tabula rasa", but within a very concrete ruins that have country and regional contours. New social groups including entrepreneurs

2 The author is ready to provide more literature to interested people 
attempting to move along new way suddenly appeared to have ,path and situation dependence", limits on their choice with the existing set of institutional resources, inherited traditions, ethics, mentality, culture, social network and relationship.

New Entrepreneurship is acting in the context of the transitional period having three levels of dependence: civilisation, macrosocial and situational.

Civilisational level - is historical memory and cultural tradition of Russia fixed by 75 years of socialist principles dominance and communist ideology. The state not only liquidated entrepreneurs physically; but tried to wipe out, to force out values and traditions of pre-Revolutionary Russian entrepreneurial ethics as well as Christian ethics and mentality on the level of the peoples culture.

The macrosocial level of entrepreneurial dependence is defined by the specifics of the transitional period. The old state has been destroyed, the new state is in the process of formation. There exists a vacuum of power and vacuum of values. Political instability, legislative heritage of the past, tyranny of bureaucracy, struggle between executive and legislative powers accompanied by the weakness of juridical power - all these are bad conditions for entrepreneurial development. Mistrust towards government and disbelieve to the state are very deep, any governmental measure inspires resistance. The fraud of the state is a deed of honour if not for all the Russian citizens but definitely for its entrepreneurial part.

The situational level is not beneficial either. The economy is still highly monopolised. There exists an obvious prevalence of the regional and natural monopolies merged with the state apparat. A big share of the decaying and degenerating military-industrial complex still influences a national economy. The population is impoverished and being accustomed to state paternalism and 70 -years equalisation envies rich people, considers businessmen as thefts and gangsters. Corruption, Mafia, decrease of demand, unpredictability of the future explains pessimism of Russian entrepreneurs oriented to survival but not to development.

Table 2: Social structure of the Russian-Soviet society (\% of the total population) (comp. Voslensky (1991))

\begin{tabular}{|c|c|c|c|c|c|c|c|}
\hline $\begin{array}{ll}\text { Social groups } & \text { Years } \\
\end{array}$ & 1913 & 1924 & 1928 & 1939 & 1959 & 1970 & 1987 \\
\hline white-collared & 17,0 & 14,8 & 17,6 & 50,2 & 68,3 & 79,5 & 88,0 \\
\hline
\end{tabular}




\begin{tabular}{|l|r|r|r|r|r|r|r|}
\hline employees & & & & & & & \\
\hline Including workers farm peasantry, & 14,6 & 10,4 & 12,4 & 33,7 & 50,2 & 57,4 & 61,8 \\
\hline $\begin{array}{l}\text { Collective } \\
\text { cooperative artisan }\end{array}$ & - & 1,3 & 2,9 & 47,2 & 31,4 & 20,5 & 12,0 \\
\hline $\begin{array}{l}\text { Non-collective-farm peasantry } \\
\text { and non-co-operative artisans }\end{array}$ & 66,7 & 75,4 & 74,9 & 2,6 & 0,3 & 0,0 & 0,0 \\
\hline $\begin{array}{l}\text { Bourgeoisie, gentry, traders, } \\
\text { kulaks }\end{array}$ & 16,3 & 8,5 & 4,6 & - & - & - & - \\
\hline
\end{tabular}

\subsection{Three Stages of Entrepreneurial Development}

1. Protoentrepreneurship of the Bredznev epoch. The curtailment of the NEP and the full state property establishment put the end to Entrepreneurship, that started to regenerate after the civil war. Former kulaks, nepmens - entrepreneurs of the NEP-time - and cooperators were the first prisoners of GULAG. Entrepreneurship was restored to life in the 60-th during the years of Bredznev regime erosion due to the cancellation of the fear component. There appeared economic and legislative niches for the alternative economy outside the system of the state planning. New entrepreneurial economy started to develop in these very niches in legal and illegal forms. There were three main entrepreneurial flows.

First - the unregistered individual service outside and inside the state service sector working without any official permission. This flow involved state enterprises employees, teachers, medical personnel, highly qualified bluecollared employees, engineers. We could include in this flow student's construction units, mining Artels, comsomolian centres of youth technical creation. During Bredznev period according to the estimates 18-20 mill. of people were occupied 1-2 month a year in this sector (2 mill. employees) having output 30 bill roubles provided coverage of demand in the service sphere of the USSR. 1987 "Individual Activities Law" allowed this activities making them legal.

The second flow is provided by the "shadow Entrepreneurship". It was born near the state enterprises producing raw materials and having industrial waste, used by this flow. By the end of 70-th the shadow economy merged with the organisational crime and peeped into the level of the state decision making. The reason lays in the centrally planned economy and administrative system crisis. The old generation of state officers brought up in fear had gone, new generation did not fear anything. The economy was too large to be managed with the help of the old managerial system, the role of the shadow economy increased 
compensating incapability of the old managerial system. The different scandals aroused: Usbekistan, Rostov, Krasnodar, Leningrad etc. That scandals were accompanied by the projects of the century: BAM; Siberia rivers conversion etc. The funds were gained by the powerful Ministries of heavy industry connected with the Ministry of Defence even before their approval by the Gosplan and afterwards billions were pumped from the budget into the „construction projects of the century". The shadow economy not expressed in the official statistics was developing rapidly and secretly under the conditions of specially created informational vacuum and hidden bureaucratic decision making by those „servants of the Soviet peoples" who acquiring strong personal network formed a system of corrupted administrative-command economy.

The third strata - the predecessors of the contemporary Russian entrepreneurs - a certain part of today's Russian supervisors of enterprises consists of the directorate. Party supervision, central provision, fixed prises, administrative restrictions, prohibitary legislation, a mass of contradictory instructions reproduced bottle-necks, discordance's and absurdities in the national economy. Muddling through these difficulties, supporting the production performance, fulfilment of the plan, wage payments demanded titanic efforts that could be called entrepreneurial. The director was and is a central key powerful figure, victimising his personal life which is really disposed to the public opinion. The director being ambitious labourholic with a high level of self-esteem and strong labour motivation was and is responsible for everything and everybody at the enterprise. An extent of risk and uncertainty of directors, specialists-managers, accountants was higher in the USSR than in any Western country. There was always bribery, illegal exchange of materials, infringe of the law that helped to soften a system and keep it alive. One of the American investigator L. Khotin's respondents - former manager of the Soviet enterprise told that he earned 200 years of prison for breaking law but not doing anything for his own benefit. The most part of the Soviet managers got several heart attacks working against the law. Everything depended and depends on the director: wages, premiums, employment, living apartment, kindergarten, etc.

2. Co-operative stage. In 1987 the Co-operative Law allowing co-operative enterprises organisation was accepted. By this time 200 thousands citizens were occupied in legal small Entrepreneurship. Under the coverage of individual labour performance a set of labour collectives got economic independence renting state property. First co-operatives were born. The pro-market Cooperative Law legalised the private business although the „sacred cow“ of state property was not murdered and private property was still officially prohibited. Most of co-operatives became private. Simultaneously, the joint ventures movement was born. It represented entrepreneurial structures independently from the type of the Soviet participant's property. 
The state sector continued to dominate absolutely in the Soviet economy through 1987-1991 by controlling the resource flows. The State enterprise Law (1987) created conditions for the state sector merging with commercial structures. That was a start-up of non-regulated and non-controlled outflow of resources from the state sector with fixed prices to the non-state sphere with flexible prices. The two-sectors economy was formed but breaching of the dam of intersector exchange became one of the generators of inflation and corruption.

Attempts of partial reforming and „human face socialism“ construction failed. New market infrastructure was created involving such elements as stock exchanges, investment and insurance companies, commercial banks, etc.

3. Post-Soviet stage of Entrepreneurship development. The august 1991 was an initial point of Entrepreneurship development oriented on the rehabilitation of the private property and large-scaled privatisation. Accepted laws, orders of the President, statements of the government were directed to the creation of private property economy.

Three stages of entrepreneurial development can be determined:

1. 60th until 1987: the limited shadow private sector under the conditions of real socialism and state property dominance;

2. 1987-1991; the partial legalisation of private Entrepreneurship accompanied by the state sector reforms;

3. from the end of 1991th: the legalisation of private property and Entrepreneurship accompanied by small and big privatisation processes.

\subsection{Ways to Entrepreneurship}

1.) „Shadow“ businessmen of all types. Sometimes these people register a company and pay taxes, sometimes the purpose is in the legalisation of the shadow activity and washing dirty money from the criminal business. These small entrepreneurs who have constant clients and want to escape from taxes usually do not expose themselves and their incomes.

2.) „New wave“ entrepreneurs. These high-qualified, well-educated specialists who are bored to death by the state system of research and scientific centres, state enterprises and ministries are typical representatives of this flow. Mathematicians, physicists and engineers are involved in this group. The military-industrial complex and the Soviet Academy of Science are a real cradle of this type of entrepreneurs. The average age of this strata is 30-40, a lot of them has $\mathrm{PhD}$ degree, high qualification, non-standard intellect, good education, is ready to reasonable risk. Their typical way of their starting-up business is computer programmes through computer trade, non-state commercial higher educational institutions creation affiliated to the biggest Universities and research centres, stock exchange, banks, holding firms development. 
3.) Party-state nomenclature entrepreneurs. The non-controlled conversion of the old bureaucratic power to new private property power on the stage of transition from the centrally-planned to the market economy is a characteristic for all postcommunist countries. The active outflow of the nomenclatura gaining party and state resources to new market structures started in 1989-1990. A set of banks, holdings, investment companies, financial groups, associations was created by the nomenclatura. The reasons of this process are: the excess to resources, the freedom of commercial structure creation during the initial period 1988-1990, the professional and personal network, their managerial skills from the Soviet time in the ministries, the party, comsomolian organisation (See Table 3).

From the beginning of reforms administrative Entrepreneurship flourished. The state organs and local administration created commodity goods and financial pools, joint ventures, trade houses, stock exchanges, so far as they have got accustomed to economic management. State post and state property management pluralism is not the usual combination because it breaks the law. But in the mainstream of the bureaucracy setting-up the latter helps to create commercial structures with a certain participation of authorities. Bureaucratic financial power has its roots in the budget money and non-budget supervision. The nonbudget finances are formed from the understated income part of the budget, from all the non-registered incomes and from the non-official rent paid by enterprises based on the authorised territory. There is no division between public Entrepreneurship of administrations and private Entrepreneurship of administrators as such, because there is neither public nor state executive control over their activities. The bureaucratic capital is formed through the activities of entrepreneurs who appeared to be commercial agents of administrations and have free of charge real estates, means of communication, credits, subsidies, chances to trade with the beneficial projects non-controllable by the public etc. Bureaucratic capital as a result of the amalgamation of state officers with private Entrepreneurship is connected with state corruption, poisons the economy with the custom to administrative monopolism and parasitism. In this liaison organisational criminality takes part, with scale, technical equipment, international ties that dangers the state itself.

4.) Red directors change the colour. One of the most beneficial positions in the Entrepreneurship appeared to be at the economic elite of the Soviet period directors and supervisors of enterprises. There are the following comparative advantages: practical experience of production management, wide social network, factual closeness to the privatised property. Directors, spontaneous privatisation began in 1991 at the civil and military enterprises. Not all the directors could be real entrepreneurs. According to the estimate only $1 / 3$ of all the directorate corpus have market economy managerial skills and qualification and could be adopted to the new market economy formation. The former Soviet directors were interested not in the fast privatisation, but also in the prolongation 
of the transitional period when they have been already independent users of state property, but still did not bear any responsibility for it. In 1995 the director's attitude to privatisation changed to $3 / 5$ negative estimate due to decreasing donations from the budget, accompanied by the raising competition and contradiction between directors, share-holders and employees. The contemporary employees dependence includes not only wage earning and apartment distribution, but also the unemployment threat and privatisation distribution. A new relationship between the directors and the employees in post-socialist enterprises developed: the employees keep loyalty in relation to director's privatisation, the directors keep the employees at the working places. Besides directors together with trade unions and employees press the government pursuing political goals.

Table 3: Ways ot the Communist Party nomenclatura (comp. Afanasyev M., 1996)

\begin{tabular}{|l|c|c|c|c|}
\hline \multicolumn{1}{|c|}{ Communist party: } & \multicolumn{2}{|c|}{ First secretaries of the } & \multirow{2}{*}{$\begin{array}{c}\text { Reads of district } \\
\text { executive } \\
\text { committees (50) } \\
\text { committees (50) }\end{array}$} & $\begin{array}{c}\text { Total } \\
\text { committees } \\
(41)\end{array}$ \\
\hline $\begin{array}{l}\text { Stayed on the } \\
\text { supervisory } \\
\text { administrative posts }\end{array}$ & 8 & 5 & 20 & 33 \\
\hline $\begin{array}{l}\text { Moved to state } \\
\text { enterprises }\end{array}$ & 16 & 18 & 11 & 45 \\
\hline Moved to private sector & 19 & 13 & 14 & 46 \\
\hline Left the region & 7 & 5 & 5 & 17 \\
\hline
\end{tabular}

\subsection{Entrepreneurship and Criminalisation of the Economy}

At one of the government meeting Prime-Minister Victor Tchernomirdin informed that $42 \%$ of Russian economy is shadow. During 10 month of 1996 about 139 thousands of crimes have been performed and $72 \%$ are considered to be of economic nature. The GDP in 1994-1996 was equal to nearly 600 bill \$ and according to the estimate of experts 30 bill or $5 \%$ are refereed to criminal incomes. The average criminal incomes per capita in Russia approached 200 \$ that exceeds the world indicator of $100 \$$.

The spheres of economic criminality can be classified this way:

1.) bank fraud, in the first place stealing of money with the help of false bank documents and guarantees, financial fraud and breach of trust of supervisors. The main object of crime is beneficial state credits, their non-purposed use, insurance, pension schemes; 
2.) non-licensed activities of commercial structures connected with the physical and juridical persons trust investments;

3.) money, securities, stampels, blanks falsification

4.) bribery connected with the credits, cash money, current accounts opening, acceleration of financial and official documents passing through the bureaucratic channels;

5.) large-scaled illegal strategical raw materials export;

6.) illegal export with the help of understated contract prices. The difference are divided between foreign and national partner;

7.) hard currency illegal export with the help of non-real contracts on commodity-goods import;

8.) illegal import of goods with the help of inner customs transit;

9.) alcohol illegal trade;

10.) precious metals, gold and brilliants theft;

11.) falsified goods and food trade;

12.) struggle for division of property, participation in privatisation, understatement of the value of privatised property; participation in illegal privatisation, infringing of tender and auctions order etc.

According to the estimates $50 \%$ of the black money are directed to bribery, $25 \%$ for hard currency export, $25 \%$ for further enrichment.

General Lieutenant Alexander Dementjev, the head of the Department of Economic Crime of the Ministry of the Inner Aaffairs in the interview to the journal „Expert" of 1996 concluded that

- the main part of economic crimes are made by the white-collared criminals bureaucrats who controls $90 \%$ of the shadow capital and only $10 \%$ is the bandit's share;

- there is an alliance of economic and criminal offence;

- the criminality is in the process of internationalisation. In 29 countries there are 200 clans of Russian Mafia acting.

\subsection{New Entrepreneurial Mentality Formation}

There are three grounds for ethics, philosophy and mentality formation for the contemporary entrepreneurs of Russia: 1. deep Russian ethics and archetype of a person described in the first part of the paper and which influences the second and third grounds; 2 . mentality and ethics of the Soviet period; 3. criminalization of the post-Soviet economy. 
The first ground still exists: the communal consciousness of the traditional society, its client-patron character, spiritual priority over material, width of the soul, God's mission consciousness, faith in the absolute and ideal utopias, contempt and ignorance of law, non-popularity of political activities and wealth. Between personal characteristics we could point out patience, kindness, carelessness and negligence in details, unreliability, irresponsibility, periodical passiveness converted into the periods of extreme activity. The analysis of the entrepreneurial group (in Russia that is 7\% of the population or nearly 5 mill. of people) shows its collective portrait features: activity, ambitiousness, high intellectual level, unscrupulousness and absence of principles, disrespect to law and inspiration to overcome and deceive it. New Russian entrepreneurs are divided into respected and non-respected groups provided that the criteria of respectability compared to the pre-Revolutionary period changed. This criteria now changed in connection with the shift of the system of values where power and money became a symbol of success. Respectable entrepreneurs are rich, with high monopolistic market share, having personal network within state bureaucracy and Mafia. In the Soviet period the criteria of success and symbol of respectability and elite attachment was belonging to cultural, scientific and artistic intelligentsia, professionalism, intellect etc. (comp. Afanasyev (1996).

Ethics of new rich Russian entrepreneurs is closely connected with the criminal world. 21 interviews with the representatives of St. Petersburg bandit world, done in the framework of the Institute of Sociology (St. Petersburg affiliate of the Russian Academy of Science) reflect this liaison. In general Russian entrepreneurs are connected with a criminal world according to the pressure of circumstances of business environment in Russia. Few of the bandits came from the criminal world itself. Pattern of this criminalization is very simple: entering into business with a serious desire to work and act fairly and honestly, fast understanding that it is impossible due to the state corruption, state and bandit racket.

A strict system of rules, of behaviour and ethical norms - a certain Code of Honour or rules of a game - where the bet is one's life either lives of one's family exists in business. Obedience to the law is not included in this Code because the state strangulates independent businessmen not connected with bureaucratic capital with raising taxes. To deceive the state is not a deed of honour but just everyday norm and an extent of the deceit depends on power, courage and intellect. Any strength is respected: intellectual, physical, financial.

Table 4: Basics of old and new Russian Entrepreneurship mentality

\begin{tabular}{|c|c|}
\hline New Rich Russians mentality & Eastern mentality \\
\hline $\begin{array}{l}\text { Two basis of the connection between God and } \\
\text { a person: on intuition faith in God's Love and } \\
\text { Mercy and on the contract basis: East-West }\end{array}$ & $\begin{array}{l}\text { connection between God and a person based } \\
\text { on God's Love and Mercy. }\end{array}$ \\
\hline
\end{tabular}




\begin{tabular}{|c|c|}
\hline „double faith“, width of the soul East & „double faith“, width of the soul \\
\hline $\begin{array}{l}\text { practical interest prevailing under mental } \\
\text { mood with the existing spiritual priority over } \\
\text { material: East-West }\end{array}$ & $\begin{array}{l}\text { prevailing of spiritual basics over the } \\
\text { material. }\end{array}$ \\
\hline $\begin{array}{l}\text { ignorance and disrespect of the law, } \\
\text { development of the consciousness of the } \\
\text { individual property rights legality: Wild } \\
\text { capitalism }\end{array}$ & "Faith, God's blessing, not the law". \\
\hline $\begin{array}{l}\text { raising individualism of a person. Orientation } \\
\text { to individual values and the cult of the } \\
\text { personal success. Still existing communal } \\
\text { consciousness, its client-patron character: } \\
\text { East-West }\end{array}$ & $\begin{array}{l}\text { raising of collectivism and communal } \\
\text { consciousness. Unification idea is non- } \\
\text { economic, spiritual, irrational faith in the } \\
\text { Absolute Ideal. Particular interests of } \\
\text { different strata's and social groups are } \\
\text { integrated for the sake of the common } \\
\text { purpose achievement. }\end{array}$ \\
\hline non-popularity of political activities: East & non-popularity of political activities \\
\hline bureaucratic capital formation & bureaucratic capital formation \\
\hline $\begin{array}{l}\text { opposition to the state, inspiration to save the } \\
\text { business from the state: East }\end{array}$ & opposition to the state \\
\hline wealth as a symbol of success: West & sinful character of wealth \\
\hline \multicolumn{2}{|l|}{$\begin{array}{l}\text { Ethics of new rich Russian entrepreneurs is } \\
\text { connected with organisational crime. }\end{array}$} \\
\hline respect to education & respect to education \\
\hline
\end{tabular}

What is the level of disrespect to the law and mentality of juridical disobedience? Could the psychology be changed? Whether a businessmen become honest when he becomes rich or when a state could be less suppressing and it will be non-profitable to break and violate legislative norms?

The replies were different but the most part of businessmen prefers the first variant: to be wealthy, invest money either to the national economy or abroad and not to violate the law. Few replies were different: for those businessmen who are satisfied with the process of enrichment and consciousness of the power over people and who always lack power and money. They would break laws whether they live in the transitional or civilised economy.

The relationship to wealth is included into the ethical norms. As distinct from pre-revolutionary Russia the estimate of and attitude to wealth are very relative because of the sudden polarisation of the post-Soviet society and conversion of $73 \%$ of the Russian population (who was not very rich but well-being in the 
Soviet time) into the poor social group. The difference between Russian and Western society wealth and poverty in the contemporary Russia is very obvious and leap to the eye. There exists a big difference between groups of new rich as well. One feels poor because he does not have a villa in the suburbs of Paris, the other thinks that wealth in Russia is not wealth due to the political instability. The instability (including a lot of not-obvious juridical norms; contradictions in the laws etc.) in Russia is a very good business environment not only for this type of businessmen but for all Russian Entrepreneurship because one could always either bribe a bureaucrat or use a good lawyer to deceive or to muddle through bureaucratic obstacles.

The bandit-respondents have no hate to the police as far as imprisonment, search or detentions are ordinary parts of their lives. They think it is stupid to oppose a state power and accept very calmly the appearance of the police with machineguns.

One of the indicator of the new rich world belonging is their appearance and outside features of "toughness" reflecting professional and financial growth. In the beginning of the career skin leather jackets and sport suits for the racket of the small businessmen, then - crimson raspberry woollen jackets, then very expensive business suit and Mercedes, BMW or Jeep represents development stages and features of respectability. There is a very interesting tendency in this group concerning inspiration of the most capable persons to real (not bought diploma) education, changing of language that could not be converted so very quickly as a suit. The common feature of all the respondents is the attitude to their children. All the 21 gangsters replied negatively to the question whether they want their children to inherit the same criminal business, the same problems of fighting with the other Mafia clans. What they want for the children - good education, may be international, raising up business to the other level. That business could have a criminal coverage but there would be another people to deal with these problems.

The results of "social intervention" in the group of "civilised" businessmen discovered the same feature of disrespect to law, the same inspiration to save the business from the state, even immigrating together with capitals abroad, the similar respectful attitude to education, inspiration to enlightenment and selfeducation or studying in the best prestigious Universities or business schools of Russia for themselves and their children. This group of entrepreneurs in comparison with the gangsters wants legislative improvement to be more persistent and successive for the future of their business and future of their families. They have wide overview of the general social and economic situation in Russia and think that Russian population needs market enlightenment and education as well as change of mentality and ethical norms. Besides political stabilisation they draw attention to the following processes that could lead to the development of new mentality: 
1) favourable public opinion;

2) growth of quantity and quality of new private enterprises;

3) market infrastructure development;

4) business schools further development and reforming of high school education oriented to economic education;

5) enlightenment of Russian population through mass media;

6) philanthropy and charity development;

7) cultural and social business environment formation.

One more factor of business strata mentality is their participation in political life and patriotism. The lower cultural and educational level of the businessmen, the more pragmatical they are considering Russia as a source of cheap labour and raw materials which are supposed to be used before their possible immigration to the West in case if the situation in Russia will come from bad to worse. Their attitude to Russia is expressed in the formula: „I am a patriot of my capital and consider its liquidation as immoral".

A contradiction between the wish to keep distance and step aside from politics and impossibility to escape politisation for defending one's own interests always existed in Russia. According to the opinion of the largest part of Russian businessmen the open political activity is contra-indicated for entrepreneurs (Lapina (1993). It is necessary to choose: or business, either politics. On the first stage of democratic reforming Russian entrepreneurs of new wave were the first to take part in demonstrations, strikes etc. in comparison with the shadow businessmen who never disposed themselves in open political activities. New entrepreneurs in 1991 were elected in the State DUMA trying to stand for their interests and create their professional unions and associations. But the most part of them prefer not to participate openly in political life but interfere and influence the political decisions secretly, lobbying, supporting the needed politics and necessary political decision financially.

\section{References:}

Afanasyev M. (1996): Ruling elite of Russia, International Economics and International Relations, No. 3, Moscow (russ.)

Berdayev N.A. (1990): Roots and contents of russian communism, Moscow (russ.)

Berch, V.N. (1831/33): Chronological history of discovered islands, or feats of Russian merchantry, Sankt Petersburg (russ.)

Bulgakov S.N. (1992): The Orthodoxy, doctrine reviews of the Orthodox Church, Kiev (russ.)

Chromov P.A. (1988): The economy reviews of pre-capitalist Russia, Moscow (russ.) 
Kusnezova, N. P. (1997): Roots and Philosophy of the Russian Entrepreneurship, Discussion paper No. 88, Wirtschaftswissenschaftliche Fakultät der Europa-Universität Viadrina, Frankfurt (Oder)

Lapina N. (1993): Entrepreneurs in the political space, Moscow (russ.)

Levschin V: (1812): The full Russian factory-owner and manufacturer, Moscow (russ.)

Touraine A. (1981): The Voice and the Eye. An Analysis of Social Movements, Cambridge

Voslensky M. (1991): Nomenklatura - power of Soviet society, Moscow (russ.) 